\title{
Mia Couto - a proclamação da Leoa: na linha de fogo...
}

\author{
Mia Couto - the proclamation of the Lioness: on the firing line...
}

\author{
José PAULO CRUZ PEREIRA \\ Universidade do Algarve
}

\begin{abstract}
Resumo: Esta leitura do romance $A$ confissão da Leoa, do escritor moçambicano Mia Couto, acompanha nele as questões da animalidade do homem e da violência na relação entre os géneros, ambas colocadas do ponto de vista ético e político. A narrativa do romance reparte-se significativamente por dois olhares diferentes: o do caçador Arcanjo Baleiro, e o de Mariamar, uma das mulheres da aldeia na qual - identificada com a leoa do título - se recortará a figura da histérica, irredutível às imposições do simbólico estabelecido pela tradição do lugar de Kulumani... Os acontecimentos transpõem, da alegoria cosmológica inscrita na fábula aí contada por Martina Baleiro - a mãe do caçador - as tensões e as assimetrias produzidas pela violenta fronteira que, entre o feminino e o masculino, uma certa escrita, subversora de todas as formas de domínio, mostrará ser historicamente instável.
\end{abstract}

Palavras-chave: romance; política; soberania; alteridade; género.

\begin{abstract}
My reading of the novel Confession of the Lioness, by the Mozambican writer Mia Couto, follows the questions of the animality of man as well as those of the violence in the relationship between genders, both posed from an ethical and political perspective. The novel's narrative is significantly shared by two distinctive viewpoints - that of the hunter Arcanjo and that of Mariamar, one of the women identified with the lioness of the title, but also the hysterical figure that resists the symbolic order of traditional Kulumani... The events and the characters of the novel transpose the cosmological allegory inscribed in the fable told by Martina - the hunter's mother - the tensions and asymmetries there set by the violent boundary that separates the masculine from the feminine, and which a subversive writing that undermines all kinds of dominion eventually suspends, and proves to be historically unstable.
\end{abstract}

Keywords: novel; politics; sovereignty; otherness; gender.

Uma das histórias que, no romance $A$ confissão da Leoa - da autoria de Mia Couto - se contam é a da "lenda da terra natal" de Martina Baleiro, mãe de Arcanjo, o caçador a quem caberia a eliminação dos leões que assolam a aldeia de Kulumani. A sua importância decorre da matriz simbólica que nela se acolhe, com a força propulsora de um princípio motor da sua construção ficcional. A essa "lenda" - diz-nos Arcanjo - Martina contava-a como sua "historieta preferida":

Antigamente não havia senão noite. E Deus pastoreava as estrelas do céu. [...] Nesse tempo, todas as estrelas comiam, todas luziam de igual alegria. Os dias não haviam nascido e, por isso, [...] tudo era tão lento no infinito do firmamento! Até que, no rebanho do pastor, nasceu uma estrela com ganância de ser maior que todas as outras (ibidem, p. 34).
Que sucede então? De que singular "estrela" se trataria?

\footnotetext{
Essa estrela chamava-se Sol e cedo se apropriou dos pastos celestiais, expulsando para longe as outras estrelas que começaram a definhar. [...] Com o Dia, os homens esqueceram-se dos tempos infinitos em que todas as estrelas brilhavam de igual felicidade. E esqueceram-se da lição da Noite que sempre tinha sido rainha sem nunca ter que reinar (ibidem).
}

A que se deveria, então, a preferência de Martina? Poder-se-ia imaginá-lo. Pois ela vem a morrer vítima da prática tradicional do Kusungabanga: "antes de emigrar para trabalhar, há homens que costuram a vagina da mulher com agulha e linha. Muitas mulheres contraem infeções. No caso de Martina essa infeção foi fatal" 
(ibidem, p. 219). Ora, lembrando-se daquela "historieta preferida" de sua mãe, e interpretando-a à maneira de um apólogo, Arcanjo aí situará a noite que o "desperta”...

Recordo a fábula de minha mãe, condenando a petulância do sol e o modo como eu mesmo, talvez por causa dessa lenda, me sinto despertar sempre que começa a escurecer. Não sou do dia, não sou da noite. O poente era a hora em que eu retornava a casa, exausto das minhas brincadeiras, nesses pátios que se abriam como uma extensa savana onde me imaginava caçando (ibidem, p. 73-74).

Com efeito, toda a "fábula" de Martina se articula note-se - em torno de uma certa "diferença sexual". Essa diferença surge, por um lado, ligada a duas formas distintas de soberania e, por outro, a duas divergentes concepções do universo. Com feições de enunciação mítica ela baliza, além disso, no seu desdobramento narrativo, dois tempos marcadamente diversos: o de uma remota origem - já alheada de si mesma, no seu in illo tempore... - e o da abrupta instalação de uma nova ordem. Instaurada pelo advento da luz do Dia - e não obstante a sua eventual pretensão à visibilidade plena - essa soberania do Sol envolve, contudo, não apenas uma certa margem de ocultação, mas também um certo fundo de cegueira. Por um lado, em virtude do eclipse a que seriam, então, votados os restantes astros desse apascentado rebanho. Por outro - com a aceleração implicada pelo advento da sua luz - pela perda do sentido, quer de uma lentidão que caracterizara, outrora, os "tempos infinitos do firmamento", quer do sentido diferencial do espaço que lhe corresponderia... Dupla exclusão: a implicar, assim, não apenas uma abrupta redução de escala - motivada pela contração do universo até às dimensões do visível... mas também a aceleração infinita que tenderia a reduzir o tempo à fração imóvel do instante. Tal seria o universo da mais paralisante mesmidade ou eternidade. À usurpadora apropriação solar dos pastos celestiais corresponderia, assim, o diurno apagamento da "lição" de uma "Noite" que fora, outrora - num tempo antes do tempo... - rainha sem violência nem reinado:

Mais e mais o Sol ostentava grandeza, vaidoso dos seus domínios e do seu nome tão masculino. Ele, então, se intitulou patrão de todos os astros, assumindo arrogâncias de centro do universo. Não tardou a proclamar que ele é que tinha criado Deus. O que sucedeu, na verdade, é que, com o Sol, assim soberano e imenso, tinha nascido o Dia. A Noite só se atrevia a aproximar-se quando o Sol, já cansado, se ia deitar (ibidem, p. 34).

Situados, portanto, em campos opostos da hybris e do polemos dessa diferença - que, entre o masculino e o feminino é, antes de mais, não apenas social e histórica, mas também ética e política... - nos seus respetivos traços se antecipariam já as clivagens que atravessariam todo o universo da aldeia de Kulumani. A tensão conflitual ali instalada transpõe-se, então, nas relações de poder em que, aqui, a sua vida ganha forma. Assim é que essa solar soberania "masculina" se reinscreverá na cerimónia do Kuyola Liu - o ritual preparatório da caçada coletiva aos leões. Assim, desordenada e gradualmente aglomerados os homens, no pátio central da aldeia, e por eles ensaiados alguns passos de dança...

De repente, um dos dançarinos exclama: - Tuke kulumba! É o grito de incentivo. Então, como que empurrados por uma invisível onda, os homens batem compassadamente com os pés no chão, uma nuvem de pó envolve os seus corpos. [...] Durante um tempo os homens dançam e, à medida que rodam e saltam, vão perdendo o tino e, em pouco tempo, desatam a urrar, rosnar e sujar os queixos de babas e espumas. Então percebo: aqueles caçadores já não são gente. São leões (ibidem, p. 160).

Ora, é precisamente aqui que intervém a analogia. Pois, pelo meio...

Os homens começam a desfazer-se das suas roupas. Depois, sobre os seus corpos nus é vertida uma infusão feita de cascas de árvores [... o que] os tornará imunes a qualquer acidente (ibidem, p. 159).

\section{E entretanto:}

Nenhuma fogueira pode estar acesa enquanto decorrem aqueles banhos. Apenas depois de terminarem é que Hanifa e todas as mulheres voltarão a acender o fogo (ibidem, p. 159-160).

O centro da aldeia - "o pátio em redor do Shitala", o alpendre dos "homens grandes" (ibidem, p. 98) ... - palco do intimidante espetáculo de tal metamorfose converte-se, portanto, numa espécie de centro do universo. E será porque em seu redor tudo se suspende que Naftalinda Makwala, esposa do administrador da aldeia, se mostrará compreensiva para com a desilusão do caçador Arcanjo Baleiro:

Como eu queria estar mais presente, quem me dera eu pudesse participar do ritual! Naftalinda entende a minha desilusão: - Você é como eu, que sou mulher: ficamos de fora. Façamo-nos companhia. Não estamos bem aqui, nesta sombra? [... E, iniciada aquela dança coletiva, ela acrescenta] Pronto, a poeira já se levantou! - sussurra a primeira dama, o rosto colado ao meu. Agora, diz ela, só me vem uma raiva, não posso mais ver este espetáculo. E retira-se para as traseiras da casa, juntando-se a Hanifa que prepara uma refeição (ibidem, p. 156; 157-158). 
A mágica conversão do espaço do Shitala em centro do universo, - "a caça é uma feitiçaria" (ibidem, p. 160) - é, portanto, o que indispõe Naftalinda. De facto, àquela retirada sombra em que ambos ficam, dentro de casa, corresponderia já o espaço de uma omissão que implica o caráter privativo da condição, quer das mulheres de Kulumani, quer do estrangeiro. Em "Violence, mourning, politics", Judith Butler refletiria assim sobre o seu desrealizante efeito:

How do we understand this derealization? It is one thing to argue that first, on the level of discourse, certain lives are not considered lives at all, they cannot be humanized, that they fit no dominant frame for the human, and that their dehumanization occurs first, at this level, and that this level then gives rise to a psyhical violence that in some sense delivers the message of dehumanization that is already at work in the culture. It is another thing to say that discourse itself efects violence through omission. [...] Violence against those who are already not quite living, that is, living in a state of suspension between life and death, leaves a mark that is no mark (2004, p. 34-36).

Poderíamos, com efeito, escutá-la em trechos como estes - em que Genito Serafim Mpepe diz a sua filha, Mariamar, uma vez anunciada a chegada do caçador que a conhecera já, em outros tempos... - na comitiva dos visitantes:

- Quero-a aqui fechada quando chegar esse caçador. Está a ouvir? / - Sim. / - Enquanto essa gente estiver em Kulumani, você nem desponta o nariz fora de casa. [...] Num instante estava refeita a ordem do universo: nós mulheres no chão; o nosso pai passeando-se dentro e fora da cozinha, a exibir a posse da casa inteira. De novo nos regíamos por essas leis que nem Deus ensina nem o homem explica (COUTO, 2012, p. 29).

Ou em que Mariamar observa, enquanto se lhes prepara uma refeição:

Nós as mulheres permanecemos na penumbra. Lavamos, varremos, cozinhamos, mas nenhuma de nós se sentará à mesa (ibidem, p. 90).

Daí a amargura e o ceticismo de Hanifa Assulua - sua mãe - quando, finda a guerra civil, e regressada Mariamar, esta lhe diz:

- Seja que dia for, é bom voltar. Voltar, agora que temos paz... Sem desviar os olhos da peneira Hanifa Assulua reclamou, em surdina. Eu falava da Paz? Qual Paz? - Talvez para eles, os homens - disse. - Porque nós, mulheres, todas as manhãs continuamos a despertar para uma antiga e infindável guerra. Hanifa Assulua não tinha dúvidas. Acordávamos de madrugada como sonolentos soldados e atravessávamos o dia como se a
Vida fosse nossa inimiga. Regressávamos de noite sem que nada nem ninguém nos confortasse das batalhas que enfrentávamos. [...] - Por isso, minha filha: deixe lá na Missão essa conversa da Paz (ibidem, p. 147).

Ora, se os homens se convertem em leões - como nos mostraria o Kuyola liu... - o que acontecerá, então, com as mulheres de Kulumani, nesta infindável guerra em que, como na fábula, só depois de o sol se deitar elas regressam?

\section{Da verdade: devida e nua...}

A leoa do romance é um desses animais "comedores de gente" (ibidem, p. 81) - um desses "leões matadores" (ibidem, p.122) - que trazem a Kulumani o caçador, acompanhado pelo escritor Gustavo Regalo, encarregue de reportar os acontecimentos. Mas corresponde também, quer ao "bicho selvagem" (ibidem, p. 62) que Mariamar avista nas margens do rio Lideia - e em que ela, difusamente, sente a reencarnação de alguma das suas três falecidas irmãs: "qualquer coisa que não conseguirei nunca descrever, subitamente me rouba discernimento e o grito me irrompe do peito: - Mana! Minha irmã! [...] Silência! Uminha! Igualita!” (ibidem, p.63), quer ao felino em que Arcanjo pressentirá, por sua vez, a espectral presença de Mariamar: "A leoa continua enfrentando-me, medindo-me a alma. Há uma luz divina nos seus olhos. Ocorre-me o mais estranho dos pensamentos: que em algum lugar já havia contemplado aqueles olhos capazes de hipnotizar um cego" (ibidem, p. 182; sublinhados meus). Ela é, ainda, a fera que ataca Naftalinda - a avantajada primeira-dama local, esposa de Florindo Mkwala, o administrador da aldeia:

A esposa se oferecera como isca para os leões. O esposo tentara dissuadi-la. Em vão. A primeira-dama insistia que iria dormir, nua, ao relento, noites seguidas, até que os leões fossem atraídos e a devorassem. [...] Naftalinda adormece enquanto me mantenho vigilante, à distância. Aos poucos também cedo ao sono até que, num segundo, tudo sucede, em confusa e atabalhoada mistura. [...] Como um clarão vejo uma leoa se enovelar sobre o seu extenso corpo e as duas, quase indistintas, se abraçarem numa dança fatal (ibidem, p. 231-236).

Mas essa leoa reaparece, mais adiante, já morta... Mesmo se, pelas palavras de Mariamar, alguma espécie de espectral latência, de larvar estado intermédio... - entre a morte e a vida - nela prevalece:

Junto à estrada de Palma, na berma de areia vermelha, a leoa jaz como quem apenas repousa. [...] Não fosse a mancha de sangue por baixo da espádua e ninguém diria que estava morta (ibidem, p. 256-257). 
Note-se, no entanto que a leoa é já, também, a mulher: não apenas a que - no enovelado abraço dessa dança fatal que as torna quase indistintas... - com ela se confunde... Mas também a que lhe sobrevive:

\begin{abstract}
Aos berros acorro a ajudar a moça. A leoa se espanta perante o meu ataque. Com ímpeto que nunca antes adivinhara, cresço em força e tamanho e obrigo a leoa a afastar-se. Seria o momento oportuno para que Naftalinda escapasse. Mas ela rejeita a minha ajuda e corre, de novo, a se entregar à agressora. Num ápice rodopiamos as três, confundem-se unhas e garras, babas e suspiros, rugidos e gritos. A raiva faz-me duplicar de corpo: mordo, esgadanho, pontapeio. Surpresa a leoa acaba por ceder. Vencida retira-se como uma rainha destronada. E desaparece no escuro, para além da estrada (ibidem, p. 236-237).
\end{abstract}

O que nos levaria a perguntar, por um lado: em que sentido se deveria, então, pensar a confissão que dá título ao romance? Porque associá-la precisamente à figura de uma leoa? Questões tanto mais importantes quanto, no caso da personagem central de Mariamar - vê-lo-emos mais adiante... - nos encontraremos diante da figura da histérica em cujo material mnésico se misturarão, quer os dados da sua experiência pessoal quer os que, escutados de outrem (FREUD, 1997, p.3565), relevam de uma experiência que não é, portanto, a sua. O que nos induziria, então, a perguntar: que verdade que nela se enunciaria? Uma leitura de L'animal que donc je suis, da autoria de Jacques Derrida, poderia aproximar-nos do que aqui nos interessa sublinhar. Em primeiro lugar, pela sua relacionação com uma "autobiografia [que] se torna confissão quando o discurso sobre si não dissocia a verdade da admissão da culpa [de l'aveu] e, portanto, da falta, do mal ou dos males" (DERRIDA, 2006, p. 40). Verdade que, desde logo, se não separa do seu estatuto de dívida a saldar, da qual seria preciso "livrar-se" [s'aquiter] (ibidem). Mas:

Pourquoi devrait-on la vérité? Pourquoi appartiendraitil à l'essence de la vérité d'être due, et nue? et donc confessée? Pourquoi ce devoir de s'acquitter de la vérité, si cacher la vérité, feindre la vérité, feindre aussi de se cacher, feindre de se cacher ou de cacher la vérité n'était pas déjà l'expérience du mal et des maux, d'une faute possible, d'une culpabilité, d'une passibilité, d'une dette - d'une tromperie et d'un mensonge? (ibidem, p. 41).

Por que seria, com efeito, a verdade, necessariamente devida e nua? Não serão, estas duas exigências, contraditórias entre si? Em que poderia consistir, realmente, esse seu valor de nudez? Até que ponto seria essa nudez possível, quer na autobiografia, quer na confissão? Não se inscreverá já, nessa verdade devida - no dever da dívida que ela, assim, comportará, a partir do Outro - uma certa economia capaz de a subverter ou perverter? Se, por um lado, o dever de a saldar não procede senão do facto de, à sua reserva ou à sua ocultação, se ligar já a uma certa concepção do mal - aquele que consistiria em escondêla, ou mantê-la de reserva... - como desligar, por outro lado, a confissão da ideia de uma exposição absoluta e de uma presença plena? Seria, então, essa nudez possível? Porque:

"Je": à dire "je", le signataire d'une autobiographie prétendrait se montrer du doigt, se présenter au présent (déictique sui-référentiel) dans sa vérité toute nue. [...] J'engage ma nudité sans pudeur, dirait-il en se nommant et en repondant de son nom. Ce gage, cette gageure, ce désir ou cette promesse de nudité, on peut douter de leur possibilité. La nudité reste peut-être insoutenable (ibidem, p. 76).

Tanto mais insustentável quanto, considerada a dimensão narcísica de todo o discurso confessional, se constataria que a mentira e o perjúrio se alojariam já em toda a forma de veracidade e, portanto, no coração dessa promessa de nudez:

Quand il faut ainsi confesser le narcissisme de la confession, on admet que la culpabilité, le mensonge même et le parjure sont logés dans la véracité même, au coeur de la promesse, dans la simplicité nue et intransitive du "je suis": je suis quelqu'un d'autre, je suis suivi par quelqu'un d'autre, je poursuis un désir ou un projet, je chasse et me chasse à la fois, moi (ibidem, p.99-100).

Confessar, portanto: não seria já uma forma de concitar o Outro? De em mim o convocar? À confissão e à autobiografia - envolvendo ambas, nesta sua dimensão narcísica, a mobilização desse outro em falta, quer porque ocultado ou posto ainda em reserva, quer porque tido na sua alterante presença... - seria pois difícil separá-las uma da outra. Sobretudo, no que Jacques Derrida chamaria então o "devir-literatura do discurso" (ibidem, p. 41). Tratar-se-ia, portanto, quanto à confissão, da necessidade de se considerar, no seu horizonte, a possibilidade de um certo fingir [d] a verdade... Mas de um fingir [d]a verdade cujo refinamento poderia passar, no caso do homem como dirá Jacques Lacan... - por um certo fingimento da sua ocultação. Um fingimento da ocultação da verdade que, no entanto, no-la desse a ver. Mas que - e tudo se jogará aqui, como veremos também, no caso da histérica... - no-la desse a ver para dela nos desviar: "conhecese a história judaica que Freud conta e que Lacan cita frequentemente: porque me dizes que vais a $\mathrm{X}$, para me fazeres crer que vais a $Y$, se vais a X?" (ibidem, p. 175) - 
diz Derrida. E, de facto, diz-nos Lacan, em "Subversion du sujet et dialectique du désir":

Observons entre parenthèses que cet Autre [c'est-àdire "l'Autre comme site préalable du pur sujet du signifiant”] distingué comme lieu de la Parole, ne s'impose pas moins comme témoin de la Vérité. Sans la dimension qu'il constitue, la tromperie de la Parole ne se distinguerait pas de la feinte qui, dans la lutte combative ou la parade sexuelle, en est pourtant bien différent (1999, p. 287).

Se há, portanto, diferença entre esta espécie de logro [tromperie] e o fingimento animal é justamente na medida em que esse Outro é encarado como lugar de uma Palavra e de uma Verdade que, já inscritas nesse puro sujeito do significante - em cujo horizonte seria preciso pensar todo o sujeito humano - farão oscilar a própria noção de lugar. Dito de outro modo: se a parada sexual, bem como o combate, mostram que os animais são capazes de fingir, em que difeririam deles os humanos? Precisamente na suspensão do sentido em que - pensada no âmbito deste "puro [sujeito do] significante" (ibidem) - se jogaria, afinal, a sua Verdade. O que de nós os afastaria seria, portanto, a sua incapacidade de fingir que fingem, ou de apagar os rastos que todo o fingimento pressupõe:

Mais un animal ne feinte pas de feindre. Il ne fait pas des traces dont la tromperie consisterait à se faire prendre pour fausses, étant les vraies, c'est-à-dire celles qui donneraient la bonne piste. Pas plus qu'il n'efface ses traces, ce qui serait déjà pour lui se faire sujet du signifiant (ibidem).

A sua diferença residiria, portanto, na incapacidade de produzir uma relação de ambivalência segundo a qual: a uma verdade devida e nua, toda a confissão deveria, afinal, ao mesmo tempo que a enuncia, também poder ocultá-la. O que levantaria, por outro lado, para Derrida - a propósito desse Outro enquanto lugar do puro sujeito do significante, da Palavra e da sua Verdade - a questão, quer da sua irredutível heterogeneidade, quer do seu lugar como terceiro:

Que fait Lacan lorsqu'il pose "que le signifiant exige un autre lieu - le lieu de l'Autre, l'Autre témoin, le témoin Autre qu'aucun des partenaires"? Cet au-delà des partenaires, donc du duel spéculaire ou imaginaire, ne doit-il pas, pour rompre avec l'image et avec le semblable, se situer au moins dans un lieu d'altérité assez radicale pour qu'on doive y rompre avec toute identification d'une image de soi, avec tout vivant semblable, et donc avec toute fraternité ou toute proximité humaine, avec toute humanité? (DERRIDA, 2006, p. 181).
Se o significante exige o lugar do Outro é, portanto, como um terceiro... É, portanto - dito de outro modo a perder de vista... Como fazer dele, então, o ponto de apoio dessa diferença estanque sem, ao mesmo tempo, o reintroduzir, por uma sua estrita correspondência com o humano, numa relação de dualidade imaginária?

Ce lieu de l'Autre ne doit-il pas être anhumain? S'il en était bien ainsi, l'anhumain, la figure, au moins, de quelque divinanimalité, en un mot, et fût-elle pressentie au travers de l'homme, serait le référent quasi transcendantal, le fondement exclu, forclos, dénié, dompté, sacrifié de ce qu'il fonde, à savoir l'ordre symbolique, l'ordre humain, la loi, la justice. Cette nécessité n'agit-elle pas en secret chez Lévinas et chez Lacan, qui se croisent d'ailleurs si souvent malgré toutes les différences du monde? (ibidem).

Ora, em A Confissão da Leoa, será já da figura dessa "divinanimalidade" (ibidem) que se trata. E, com ela, daquilo que nos parece dever pensar-se como uma outra dimensão da confissão. Ela diria respeito, no imaginário das mulheres de Kulumani, a uma espécie de identificação a que aqui chamaríamos heteronarcísica. $\mathrm{O}$ que fica patente no encontro de Mariamar com a leoa, nas margens do rio Lideia:

Saciada a sede a leoa espreguiça-se como se quisesse que um outro corpo the saísse do corpo. Depois, vaise retirando lentamente, a cauda balançando como um pêndulo felpudo, cada passo uma carícia sobre a superfície da terra. Sorrio, com incontida vaidade. Todos acreditam que são leões machos que ameaçam a aldeia. Não são. É esta leoa, delicada e feminina como uma dançarina, majestosa e sublime como uma deusa, é esta leoa que tanto terror tem espalhado em todas as vizinhanças. Homens poderosos, guerreiros munidos de sofisticadas armas: todos se prostraram, escravos de medo, vencidos pela sua própria impotência. (COUTO, 2012, p. 62).

Que espécie de economia se nos propõe, então, através desta idealização desta leoa, aqui "magestosa e sublime como uma deusa" (ibidem)? Em que sentido se relaciona ela com uma ordem simbólica tradicional que se viu já ser violentamente adversa à condição das mulheres de Kulumani? Questão que nos parece fundamental. Porque uma mesma indecisão limítrofe se remarca, então, mediante a projeção desse ideal do eu (cf. LACAN, 1985, p. 79), em várias dessas mulheres. Em Maria-mar, por exemplo, ao socorrer Naftalinda das garras da leoa:

Por segundos permaneço deitada sobre Naftalinda quando [...] avisto Florindo com uma matraca erguida acima da cabeça, pronto para me desfechar o golpe final. - Sou eu! Sou eu, Mariamar! Um coro de 
vozes eclode: mate-a Florindo! Que essa mulher é a própria leoa! À nossa volta junta-se a aldeia inteira, reclamando justiça (COUTO, 2012, p. 237).

Mas também em sua mãe - Hanifa Assulua, casada com Genito Serafim Mpepe - quando ela pergunta a Arcanjo Baleiro, lá para o final do romance:

O senhor contou os leões? [...] O senhor sabe muito bem: os leões eram três. Falta ainda um. [...] Eu sou a leoa que resta. É esse o segredo que só você conhece, Arcanjo Baleiro (ibidem, p. 269-270).

E por que razão, no entanto, a um tal segredo, só Arcanjo o haveria de conhecer? Um dos alarmes da presença de leões é precisamente dado por Hanifa:

- Os leões chegaram a minha casa. Desde que anoiteceu eles rondam a aldeia. Hanifa tinha-os escutado de longe. - Não ouvi nada - confesso [responde Arcanjo Baleiro]. [...] - Hanifa, chame imediatamente Genito! - ordeno. - Ele está a dormir. De súbito, Hanifa aponta para uns arbustos que se agitam e incita: - Dispare, são leões! Dispare! O indicador sobre o gatilho torna-se tenso. [...] Contudo, neste caso, o dedo tremente, hesita. Essa demora é providencial: um vulto emerge da penumbra, mão erguidas como um espantalho bêbado. - Não dispare, sou eu, Genito! (ibidem, p. 152-153).

E é ainda Genito Mpepe quem, logo de seguida, vem a explicar-se:

Hanifa sabia que era eu. Ela sabia que era eи que estava a chegar. - Não entendo - diz Gustavo. - O que se passou aqui, sabe o que foi? Uma emboscada. Hanifa quer matar-me. [...] Ela pensa que sou culpado de coisas terriveis. - Que coisas? - São coisas nossas, vocês sabem: aqui não há polícia, não há governo, $e$ mesmo Deus só há às vezes" (ibidem, p. 153).

Hipótese, no entanto, suspensa por Arcanjo Baleiro quando descobre, "ocupado em farejar pegadas" (ibidem, p. 163): "Hanifa tinha razão, os leões andaram por aqui" (ibidem). Mas por que é Hanifa a leoa que resta? Porque ela se convence, no final do romance, conhecendo já o teor da confissão de Mariamar, da sua loucura...

\section{Vashilo-ou a sobrevivência: da/pela (contra-)imagem...}

A tensão conflitual inscrita na fábula de Martina Baleiro atravessará, assim, todo o romance. À sua luz se compreenderia a revolta de Naftalinda, a "primeira-dama" de Kulumani. A sua intempestiva irrupção pelo espaço do shitala - reservado, por tradição, às reuniões dos "homens grandes" (ibidem, p. 96)... - suspende a solene receção aos visitantes para aí vir a contestar as suas explicações acerca dos leões:

A caçada devia ser outra. Os inimigos de Kulumani estão aqui, estão nesta assembleia! - [...] E não me olhem assim que não tenho medo. Sou como os leões que nos atacam: perdi o medo dos homens! [...] - Uma mulher foi violada e quase morta, nesta aldeia. E não foram leões que o fizeram. Já não há lugar proibido para mim. [...]-Fingem que estão preocupados com os leões que nos tiram a vida. Eu como mulher pergunto: mas que vida há ainda para nos tirar? [...] Sabe porque não deixam as mulheres falar? Porque elas já estão mortas. Esses aí, os poderosos do governo, esses ricos de agora, usam-nas para trabalhar nas suas machambas (ibidem, p. 124-125).

A sua intervenção não visa apenas Florindo Mkwala, o administrador, representante destes "ricos de agora", "poderosos do governo" (ibidem, p. 125). Enfrenta, também, os "homens grandes": "sou como os leões que nos atacam: perdi o medo dos homens"... E a sua indignação - "que vida há ainda para nos tirar? [...] Porque elas estão já mortas..." - dir-se-ia dar voz a uma ideia já ponderada. Uma ideia que se antecipara já, nas palavras de Hanifa a Mariamar:

- Esta aldeia matou a sua irmã. Matou-me a mim. Agora, nunca mais mata ninguém. / - Por favor, mãe. Acabámos de enterrar uma de nós. / - Nós todas, mulheres, há muito que fomos enterradas. Seu pai me enterrou; sua avó, sua bisavó, todas foram sepultadas vivas. Hanifa Assulua tinha razão: talvez eu, sem saber, já estivesse enterrada. De tanto desconhecer o amor, eu já estava sepultada. A nossa aldeia era um cemitério vivo [...] (ibidem, p. 49-50).

Com efeito, aproveitando o entusiasmo do escritor Gustavo Regalo pelo Kuyola liu, Naftalinda lhe perguntará, por sua vez, a dada altura:

- Quantos homens estavam na cerimónia? / - Talvez uns vinte. / - Os outros eram doze. / - Os outros? Que outros? / - Os que mataram Tandi, a minha empregada. Eram doze. Alguns desses estavam dançando à vossa frente. / - Mataram-na? / - Mataram a alma dela, ficou só o corpo. Um corpo ferido, uma réstia de pessoa. Relatou então o que sucedera: inadvertidamente a empregada atravessou o mwe-ra, o acampamento dos ritos de iniciação para rapazes. O lugar é sagrado e é expressamente proibido a uma mulher cruzar aquele território. Tandi desobedeceu e foi punida: todos os homens abusaram dela (ibidem, p. 161).

Violada por esses doze homens - quais apóstolos da tradição... - nem cuidados de saúde lhe chegariam a 
ser prestados: "A moça foi conduzida ao posto de saúde local, mas o enfermeiro não quis tratar dela. Tinha medo da retaliação" (ibidem). Ninguém quis saber. Nem "as autoridades distritais [que] receberam queixa e nada fizeram. Quem, em Kulumani, tem coragem de se erguer contra a tradição?” (ibidem). Nem Florindo Mkwala, o administrador: "- Meu marido ficou calado. Mesmo quando o ameacei ele nada fez [...]. Não sei o que vão procurar pelo mato. Esse leão está dentro da aldeia" (ibidem). Razão pela qual discursa no funeral de Tandi:

Tandi foi a enterrar, manhã cedo. Há pouca gente no funeral. Mulheres, sobretudo. [...] Naftalinda está desfeita. A certo momento, quer tomar da palavra. O choro, porém, impede-a de falar. Recompõe-se, enxuga a lágrima e, aos poucos, assume a gloriosa pose da exaltação: - Os leões cercando a aldeia e os homens continuam a mandar as mulheres vigiarem as machambas, continuam a mandar as filhas e as esposas coletar lenha é água de madrugada. Quando é que dizemos que não? Quando já não restar nenhuma de nós? (ibidem, p. 209).

E razão, também, para uma velada alusão à sua pessoa surgir nas sibilinas palavras que Ápia Nwapa, a feiticeira que - consultada, por insistência do escritor Gustavo Regalo, sobre o caso de um osso humano recentemente encontrado na boca de uma hiena... - diz a Arcanjo: "Uma mulher deitada por terra, caiu mais fundo que a poeira. No fim, alguém vai engravidar de um esqueleto" (ibidem, p. 188). O que se vem a descobrir por Maliqueto Próprio, o polícia-verdugo da aldeia, é que:

- Esse éo osso de Tandi, a empregada do administrador, essa que foi violada... Os gritos na aldeia reiteram o luto: já se espalhou a notícia da nova vítima dos leões assassinos. Que tenha sido Tandi ninguém se surpreende. Depois de ser violada, a moça tinha-se convertido num vashilo, um desses seres sonâmbulos que atravessam as noites. Assim, exposta e solitária, ela se entregou à voracidade dos leões. Tandi tinha-se suicidado (ibidem, p. 188-189).

De que se trata então? O vashilo aproxima-se mesmo ainda em vida de Tandi: "mataram a alma dela, ficou só o corpo. Um corpo ferido, uma réstia de pessoa"... - dessa entidade fantasmática que, na sua referência à larva dos latinos, Giorgio Agamben nos descreve, no seu O Poder Soberano e a Vida Nua:

A primeira consequência da morte é, na verdade, libertar um ser vago e ameaçador (a larva dos Latinos, a psychê, o eidôlon ou o phasma dos Gregos) que volta com as semelhanças do defunto aos lugares por ele frequentados e não pertence propriamente nem ao mundo dos vivos nem ao mundo mortos (1998, p. 97).
Seria precisamente para evitar tais regressos que, vinda do cemitério onde Silência acaba de ser enterrada, Mariamar "apagava as pegadas que conduziam à sepultura (ibidem, p. 176-177) e Hanifa passava no rio "para os banhos purificadores": "Hoje eu sei: colocamos uma lápide sobre os mortos, não é por respeito. Temos receio que regressem. Esse medo, com o tempo, torna-se maior que a saudade" (ibidem, p. 177). Além disso, contudo, a descrição de Agamben prendia-se já, no contexto da sua análise do conceito de soberania, com o estatuto de uma figura particular do direito romano antigo: a do homo sacer - o "homem sagrado". A singularidade da sua condição de homem banido, - "sagrado" porque separado... - prendiase com o facto de, pelo abandono jurídico a que então é votado, ele poder ser morto sem que, a tal cometimento de homicídio, se atribuísse qualquer espécie de penalidade. Agamben vê, por isso, o homo sacer como uma instância simétrica da figura do soberano, pois também ele se situaria num certo exterior da lei - simultaneamente na origem e acima dela:

Nos dois limites extremos da ordem jurídica, o soberano e o homo sacer apresentam duas figuras simétricas que têm a mesma estrutura e são correlatas, no sentido em que o soberano é aquele para o qual todos os homens são potencialmente homines sacri, e homo sacer é aquele em relação ao qual todos os homens agem como soberanos (ibidem, p. 85).

Cerca de dez anos mais tarde, em A Potência do Pensamento - mas agora a propósito do que chama "A Imagem Imemorial" - o autor retoma a sua formulação inicial para the acrescentar que:

O objectivo dos ritos fúnebres é precisamente o de transformar este ser incómodo e ameaçador, que não é senão a imagem do morto, que obsessivamente retorna, num antepassado, isto é, ainda uma imagem, mas benévola e separada do mundo dos vivos (2005, p. 288).

E esta segunda referência enfatiza já, com efeito, a sua condição de imagem. O estatuto do homo sacer não seria, na condição que o seu banimento lhe impõe, mais que o da imagem de um homem: o da sua enlutada sombra, o do seu antecipado fantasma. Exposto à morte sem homicídio e impassível de sacrifício - o seu abandono pelo direito divino o dará como "insacrificável" (AGAMBEN, 1998, p. 83)... - ele está já morto: mesmo ainda em vida... Tal como aconteceria com Tandi e, bem vistas as coisas, com todas as mulheres de Kulumani... Como se, nesse seu fantasmático descolamento do seu próprio ser, a sua imagem lhe(s) sobrevivesse já. À maneira do que aconteceria em certas práticas funerárias antigas, essa imagem seria, então, como o signum ou o 
“"colosso' [... o] duplo, que ocupa o lugar do cadáver que falta numa espécie de funeral per imaginem" (ibidem, p.97), quando o corpo do cadáver se perde ou não recupera. A impunidade do seu homicídio lembranos aquela em que, em "todo o discurso canonizado e hegemónico das metafísicas e das religiões ocidentais" (DERRIDA, 1992, p. 292), - diz-nos Jacques Derrida, em "'Il faut bien manger' ou le calcul du sujet" - é tida a morte do animal:

Je ne sais pas si "structure sacrificielle" est l'expression la plus juste. Il s'agit en tout cas de reconnaître une place laissé libre, dans la struture même de ces discours qui sont aussi des "cultures", pour une mise à mort non criminelle: avec ingestion, incorporation ou introjection du cadavre. Opération réelle, mais aussi symbolique quand le cadavre est "animal" [...] opération symbolique quand le cadavre est "humain" (ibidem, p. 292-293).

Decorrendo da sua condição de fora-da-lei, de ausente da lei por exclusão ou omissão, essa impunidade situar-se-ia já - sendo ela própria exemplar de um certo "carnologo-falocentrismo" - no entanto, entre dentro $e$ fora da lei:

O ser fora-da-lei pode sem dúvida, por um lado, e é a figura da soberania, tomar a forma do ser-acima das leis, e portanto a forma da própria Lei, da origem das leis, do garante das leis, como se a Lei com L grande, a condição da lei, estivesse antes, acima e portanto fora da lei, exterior, isto é, heterogénea à lei; mas o ser-fora-dalei pode também, por outro lado, e é a figura do que o mais das vezes se entende por animalidade ou bestialidade, situar o lugar em que a lei não aparece, ou não é respeitada, ou se faz violar (DERRIDA, 2004, p. 60-61).

O que haveria seria, pois, uma relação de participação sem pertença entre $o$ soberano e $a$ besta... Ora, não sendo "um animal", Tandi representaria, no entanto, um certo limite da ordem jurídica tradicional: presa da sua fúria persecutória, ela é a sua exemplar vítima "sem homicídio". Perguntar-se-á Judith Butler, em Precarious Life, quanto à condição espectral que, então, lhe cabe:

How do our cultural frames for thinking the human set limits on the kinds of losses we can avow as loss? After all, if somenoe is lost, and that person is not someone, then what and where is the loss, and how does the mourning take place? If violence is done against those who are unreal, then, from the perspective of violence, it fails to injure or negate those lives since those lives are already negated (2004, p. 32-33).

$\mathrm{O}$ que nos explicaria a indiferença dos poderes tradicionais para com a morte de Tandi. Mas justi- ficaria, também, a inquietação que ela acabará por provocar:

But they have a strange way of remaining animated and so must be negated again (and again). They cannot be mourned because they are always lost or, rather, never 'where', and they must be killed, since they seem to live on, stubbornly, in this state of deadness (ibidem, p. 33).

Naftalinda reconhecerá, pois, nesse destino de Tandi - "a desrealização do Outro significa que ele não está nem vivo nem morto, antes permanecendo interminavelmente espectral" (ibidem, p. 35-36) - precisamente a condição de uma omissão que, imposta às mulheres de Kulumani, se veria denegada pela "tradição". E já nisso desafiaria ela o soberano poder desses "leões-matadores" (COUTO, 2012 , p. 122) que, a seu ver, continuavam dentro da aldeia... Ao expor-se ao seu ataque, ela repetiria já, com efeito, o gesto de Tandi: entre sonâmbulo e suicida... Como se dela, finalmente, Naftalinda tivesse recebido o testemunho da sua condição de vashilo. O que, de resto, se pressentiria já, à sua chegada a Kulumani, quando, integrada na comitiva dos visitantes, observa:

Estamos a chegar de noite. Alguns pensam que nós somos vashilo. I - Quem? - Vashilo, os da noite. Somos os únicos que, a esta hora, andam visitando as aldeias (ibidem, p. 85).

E, no entanto, embora a tragédia que sobre Tandi se abate nos pareça representar, pela sua exemplar crueza, o ponto culminante do drama social, histórico e político inscrito na condição das mulheres de Kulumani, a cada uma dirá ela respeito de modo diferente. A Naftalinda caberiam, também, razões só suas:

Olha bem para mim! Olha sem medo, somos ambas mulheres. Como pode um homem desejar-me a mim? Como posso seduzir Florindo, diz-me? / - Não faças isso comigo - suplico-lhe. I - O que te disse Florindo? Disse-te que me ofereci para refeição de leão? Ora, ele não entendeu. Eu quero ser comida, quero ser comida no sentido sexual. Quero engravidar de um leão (ibidem, p. 235).

Engravidar de um leão: outra forma de engravidar da morte - ou do que dela restasse... Do esqueleto de Tandi, por exemplo - como sugerira a feiticeira Ápia Nwapa... - a quem tais "leões-matadores" (ibidem, p. 122) haviam retirado a vida... Por a terem violado, uns; por a terem devorado, outros... Ser, pois, comida por um leão: sexual e/ou literalmente... E com isso precipitar a sua vindacomo a da sua própria morte - fazendo-o aparecer de dentro da aldeia: "Ouvi dizer que os leões só matam mulheres" (ibidem, p. 78), dirá ela... Ou de fora? 


\section{Tangências: o paradigma da histérica...}

A idealizante projeção da figura dessa leoa que "delicada e feminina como uma dançarina, majestosa e sublime como uma deusa" (ibidem, p. 62) - Mariamar avista nas margens do rio Lideia inverteria, então, aquela ameaçadora redução das mulheres de Kulumani à sua antecipadamente enlutada imagem. Em Mariamar ela ganhará, contudo, visivelmente corpo:

Quem vive no escuro inventa luzes. Essas luzes são pessoas, vozes mais antigas que o tempo. A minha luz sempre teve um nome: Adjiru Kapitamoro. O meu avô ensinou-me a não temer as trevas. Nelas descobriria a minha alma noturna. Na realidade, foi o escuro que me revelou o que sempre fui: uma leoa. É isso que sou: uma leoa em corpo de pessoa. A minha forma era de gente, mas a minha vida seguia uma lenta metamorfose: a perna convertendo-se em pata, a unha em garra, o cabelo em juba, o queixo em mandíbula (ibidem, p. 253).

Que se terá passado então? Por um lado, sobre o fundo daquela memória estabelecida pelo lendário universo da fábula de Martina, a figura de Mariamar representaria, em primeiro lugar, a persistência desse noturno mundo de outrora, entretanto deposto pela soberania do sol. Lê-se, na sua primeira "Versão":

Deus já foi mulher. Antes de se exilar para longe da sua criação e quando ainda não se chamava Nungu, o atual Senhor do universo parecia-se com todas as mães deste mundo. Nesse outro tempo, falávamos a mesma língua dos mares, da terra e dos céus. $\mathrm{O}$ meu avô diz que esse reinado há muito que morreu. Mas resta, algures dentro de nós, memória dessa época longínqua (ibidem, p. 15).

Além disso, a sua vida cruzaria ainda, no presente, dois estratos diferentes: o da tradição patriarcal que, já posterior à memória dessa época longínqua, a vem deslocar, e o das marcas deixadas pela guerra civil. Como dirá o cego da aldeia:

A guerra é que explicava a tragédia de Kulumani. Repetia-se, agora, a mesma desarrumação de todas as guerras: as pessoas tornaram-se animais e os animais tornaram-se gente (ibidem, p. 119).

Por outro lado, marcado por uma espécie de regressão simbólica - do dia para a noite, do humano para o animal, do canto para o silêncio: "tive uma mãe que cantou só para mim"... - o seu percurso revelar-se-á como o de uma espécie de histerização. Em que sentido? Em Newly Born Woman, Catherine Clément reexamina, cuidadosamente, o conjunto das posições freudianas sobre a histeria. Todas elas se ligariam, inicialmente, nos manuscritos de Freud, ao pressentido trauma de alguma "sedução pré-sexual" ("pré-púbere"). Essa sedução seria ali atribuída, quer à figura paterna quer, posteriormente, a outras figuras masculinas da família...

The hysteric suffers from Symbolic transgression as much as she suffers from memories. In her kinship relations, she suffers because her father, her brother, and her brother-in-law come to act as sexual agressors, arousing feelings that will convert to sufferings, to hangups, to aesthetic points-anesthetic or hyperestethic. So the guilty one is unmasked (1996, p. 44).

Mas essas posições iniciais ver-se-ão todavia, irremediavelmente postas em causa pela descoberta de que o material mnésico analisado inclui, também, o registo - que com ele se (con)funde... - de "fantasias [que] procedem de coisas ouvidas e só depois aplicadas" (FREUD, 1997, p. 3565). Observa, então, Catherine Clément:

The mecanism becomes clear. Reality is framed by language, spoken and heard. Somewhat later, in ' $M$ ' manuscript, Freud formulates the fantasy as distortion and fusion, but he particularly attributes an objective to distortion. 'These tendencies aim at making recollections, which could or might cause symptoms, inaccessible... This process makes the discovery of the original connexion impossible'. There you have it: one will never know, hence it all risks - how would we know? - being distorted. Falsified? False? The reality of the seduction disappears (1996, p. 47).

Diante desta espécie de inamovível reserva - aqui suscitada, note-se: pela descoberta de um certo elemento de ficção ou de ambivalência, assim introduzido nas "confissões" da histérica... - que nos diz, então, a "Versão de Mariamar"?

Hoje sei: a história da minha infância não é senão uma meia verdade. Para desmentir uma meia verdade é preciso bem mais que a verdade inteira. Essa verdade enorme, tão vasta que me escapava, era apenas uma: não foram os castigos físicos que me fizeram estéril. Essa era a versão adocicada inventada por minha mãe. O crime foi outro: durante anos, meu pai, Genito Mpepe, abusou das filhas (COUTO, 2012, p. 200).

Que forma teria, então, revestido esse abuso? Que processos envolveria?

O inacreditável era que, no momento da violação, eu me exilava de mim, incapaz de ser aquela que ali estava, por baixo do corpo suado do meu pai. Um estranho processo me fazia esquecer, no instante seguinte, o que acabara de sofrer. Essa súbita amnésia tinha uma intenção: eu evitava ficar órfã (ibidem). 
Ora, a possibilidade de, na inapreensível meiaverdade da sua "Versão", o testemunho poder ter sido ficcionalmente construído - a partir do que ela ouve dizer... - só acentua, em boa verdade, o valor do seu testemunho. O seu processo resultaria, então - embora agora intrafamiliar... - semelhante ao de Tandi:

Tudo aquilo, afinal, sucedia sem chegar nunca a acontecer: Genito Mpepe desertava para uma outra existência e eu me convertia numa outra criatura, inacessível, inexistente (ibidem).

Espancada por sua mãe, Hanifa Assulua, - que "não se referia [já, então] a Genito como 'o meu pai'. Ele era agora "o seu homem"' e que se encarregaria de chamar um feiticeiro, para tratar do assunto - Mariamar é, então, forçada a ingerir "uma amarga poção. [...] No dia seguinte, [...] tinha sido convertida num corpo sem alma" (ibidem, p. 201). A partir de então se lhe observariam uma série de sintomas... De uma súbita paralisia dos membros inferiores (ibidem, p. 130), a inesperados distúrbios alimentares noturnos (ibidem, p. 93), a súbitos surtos de uma perturbante hiperestesia (ibidem, p. 132). Todos eles a culminar numa estranha afasia:

Repentinamente, perdi a fala, apenas um rouco farfalhar me sacode o peito. Assustada me ergo, percorro com ambas as mãos a garganta, a boca, o rosto. Grito por ajuda, mas apenas um cavernoso bramido se solta de mim. É então que emerge a esperada sensação: um raspar de areia no céu da boca como se me tivessem enxertado uma língua de gato. Hanifa surge na porta, mãos nas ancas, cobrando serviço: - Outra vez esses ataques Mariamar? (ibidem, p. 91).

Essa afasia coincide com o devir-animal que dela toma posse e agrava-se à medida em que nela se vão revezando as vozes distintas do seu ser de fronteira...

Inspiro fundo e escuto dentro de mim uma outra voz. E essa voz enche de novo a minha cabeça: não há Adjiru, não há leões feitos não há deuses remendando o passado. A verdade é bem outra: não foi a vida que me deformou. Eu já vinha à nascença, negada como mulher. Visitei o mundo dos homens apenas para melhor lhes dar caça. Não foi por acaso que as minhas pernas paralisaram. O bicho que havia em mim pedia uma outra postura, mais gatinhosa, mais junto do chão, mais perto dos cheiros. Mas também não é por acaso que sou infértil. $\mathrm{O}$ meu ventre é feito de uma outra carne, eu sou composta de almas trocadas (ibidem, p. 256).

Mas também à medida em que se apura a sua noção dos poderes da escrita. Se já a sua anterior paixão por Arcanjo "não era mais que uma súplica" - "eu apenas pedia socorro, em silêncio rogava que ele me salvasse dessa doença": "Kulumani e eu estávamos enfermos" (ibidem, p. 95) - era ainda pela sua fuga que pedia. Que a salvasse...

Como antes a escrita me tinha salvo da loucura. Os livros entregavam-me vozes como se fossem sombras em pleno deserto. [...] Ninguém mais do que eu amava as palavras. Ao mesmo tempo, porém, tinha medo de ser outra e, depois, não caber mais em mim. Tal como o avô, que esculpia madeirinhas às escondidas, eu mantinha uma incumbência secreta. A palavra desenhada era a minha máscara, o meu amuleto, a minha mezinha (ibidem, p.95-96).

Ora, observaria ainda Catherine Clément, a propósito da deserção das histéricas - pois todas elas abandonam a análise a meio: "poder-se-ia dizer que, porque tocaram nas raízes de uma certa estrutura simbólica, estas mulheres são de tal forma ameaçadas que têm de desaparecer" (1996, p. 5). Com efeito:

Societies do not succed in offering everyone the same way of fitting into the symbolic order; those who are, if one may say so, between symbolic systems, in the interstices, offside, are the ones who are afflicted with what we call madness, anomaly, perversion [...]. But this mobility is also dangerous - or productive - for the cultural order itself, since it affects the the very structure whose lacunae it reflects (ibidem, p. 7).

E conforme se constataria em La possession de Loudun, de Michel de Certeau, "os leões somos nós" (ibidem, p. 12). Com efeito, "nas imediações [da histeria] está a animalidade, a mutação dos homens em animais (ibidem, p. 13). Ora o que se nos revelará, nos cadernos da "Versão de Mariamar" é, de facto, esta espécie de proclamação que lhe imporá - diante de sua mãe, tal como diante de toda a aldeia de Kulumani, caso ainda queira de lá escapar viva... - um definitivo silêncio... Um silêncio semelhante ao de Rolando - o irmão de Arcanjo Baleiro, internado num hospital psiquiátrico, depois matar seu pai a tiro:

Quero falar. [...] Quando tento repetir, mais claro, confirmo que, mais uma vez, havia perdido a habilidade de falar. Desta vez, porém, é diferente: daqui em diante não haverá mais palavra. Esta é a minha derradeira voz, estes são os últimos papéis. E aqui deixo escrito com sangue de bicho e lágrima de mulher: fui eu que matei essas mulheres, uma por uma. Sou eu a vingativa leoa. A minha jura permanecerá sem pausa nem cansaço: eliminarei todas as remanescentes mulheres que houver, até que, neste cansado mundo, restem apenas homens, um deserto de machos solitários. Sem mulheres, sem filhos, acabará assim a raça humana. [...] Até que os deuses voltem a ser mulheres, ninguém mais nascerá sob a luz do sol (COUTO, 2012, p.258). 
Assim, se para o caçador Arcanjo Baleiro "aqueles olhos, de tanta luz, escurecem o mundo" (ibidem, p.268) é porque no seu ser de fronteira se insinuava já o mundo solar da soberania dos homens que, então, dominavam Kulumani... Pois "a histérica é bissexual: o que significa o quê? Nos ataques de histeria severos ela é, simultaneamente, 'mulher' e 'homem', diz Freud" (CLÉMENT, 1996, p.56). Assumin-do-se como “a vingativa leoa" (ibidem, p.258), Mariamar se dará, então, por autora do mesmo crime ali imputado aos leões assassinos já desafiados por Naftalinda. Ela é, pois, um ser de fronteira. Tal como Arcanjo Baleiro, que nos confessara já: "Não sou do dia, não sou da noite"... Mas da hora crespuscular a que, sobre o deserto da escrita, se libertaria um incerto volume de sombras... Compreenderse-á então, na sua áfona e gesticulada resposta, ali diante de Hanifa - "Tenho os papéis do hospital que confirmam que ela deve ser internada. A minha filha enlouqueceu" (COUTO, 2012, p.267), dirá esta ... - o que nos parece ser uma certa tangência da loucura.

Só levas esse caderno, não levas uma mala de roupa? / - Ela não fala - interfere a mãe. - Desde ontem que deixou de falar. Mariamar gesticula, apontando para o caderno. Aquele balbuciar faz-me recordar Rolando, meu pobre irmão, toda a vida tão íntimo com as palavras e agora sem acesso aos mais básicos vocábulos. A moça de olhos de mel esbraceja, a capulana abre-se em asas e a mãe traduz: - Ela diz que esse caderno é a sua única roupa (ibidem, p. 268).

Porque não fala? Em que medida essa histeria - que ela partilha, afinal, com Rolando - não é já simulada para escapar de Kulumani? O "histérico se aliena do significante-mestre como aquele [a] que[m] esse significante divide [...] aquele que se recusa a dar-lhe corpo" (LACAN, 1992, p. 88). Com efeito, as abas da capulana abrem-se-lhe no gesticulado batimento do voo pelo qual se venceria esse "lugar cercado pela geografia, atrofiado pelo medo" (Couto, 2012, p. 24). Precisamente o movimento que reencontraríamos, afinal, numa passagem livremente traduzida de "À Caça de Borboletas" de (cf. BENJAMIN, 1992, p. 124-126) e usada como epígrafe no "Diário do Caçador". Nele se leria o anelo do caçador, diante da borboleta:

Como ficaria feliz se me pudesse dissolver em luz e ar, apenas com o intuito de me aproximar e ser capaz de a dominar. Entre mim e a presa, agora, a velha lei da caça se instala: quanto mais eu, com todo o meu ser, tento obedecer ao animal, mais me converto, corpo e alma, em borboleta. Quanto mais perto estou de cumprir o desejo de caçador, mais esta borboleta ganha a forma da vontade humana (COUTO, 2012, p. 67).
Essa velha lei da caça resultaria, assim, numa lei $d a$ escrita. Pois que ela inscreve, na imagem do ser - a que dele descola, no seu espaçamento... - o desvão de uma alteridade a que o seu desejo de domínio fatalmente o submete. Não admira pois que Arcanjo - o caçador... se torne escritor: "começo [...] a ganhar o tardio gosto de escrever. Qualquer coisa na escrita me sugere o prazer da caça: no vazio da página se ocultam infinitos sobressaltos e espantos" (COUTO, 2012, p.211). Esse vazio é o espaço aberto daquele movimento em que se remarcaria já a lentidão daqueles tempos do infinito firmamento que, na fábula de Martina, seriam os da sua outrora noturna incomensurablidade. Se a borboleta aí ganha a forma da vontade humana é porque, no batimento de suas asas, estará já a sua (des)aparição. Logo na abertura de Falenas - onde se abordará a "exemplar fenomenologia da fascinação" de Walter Benjamin - Georges Didi-Hüberman nos dirá:

Como [...] uma borboleta, a aparição é um perpétuo movimento de fechamento, de abertura, de novo fechamento, de reabertura... É um batimento. Uma vibração rítmica do ser e do não-ser. [...] Toda a aparição poderia, por isso, ser vista como uma dança ou como uma música, como um ritmo em todo o caso [...] $(2015$, p. 9$)$.

Em relação a Mariamar, essa dança inscrever-se-ia já no seu próprio nome. Como lhe diz Adjiru: "-Não te dou apenas um nome [...]. - Dou-te um barco entre mar e amar" (COUTO, 2012, p. 136). Em particular no que, respeitante a esse mar, do seu nome se associaria, quer à sua origem de "assimilada"...

Tomavam-nos por criaturas de raça branca. Essa a razão de nos chamarem de dombe, que é o nome que se dá aos peixes. Desde que aqui aportaram, há séculos, que os portugueses são assim designados. Desaguados nas praias, vindos do líquido horizonte, eles só podiam ter nascido do oceano. Que era de onde provínhamos nós, eu e Arcanjo (ibidem, p. 172).

Quer ao seu ambivalente amor por Arcanjo - assimilado da mesma irrastreável origem... - quer, ainda, ao nome de sua sempre sonhada e abortada filha:

$\mathrm{O}$ que me encantou foi a espuma, os farrapos de espuma [...]. Como aves brancas, sem corpo e sem asas, esses fiapos se soltavam num voo cego para se dissolverem no ar. Nos meus lábios enrolei e soltei mil vezes a palavra "espuma". Se um dia tivesse uma filha chamar-lhe-ia assim: Espuma (ibidem, p. 205).

Esse mar suporia pois, no batimento das suas asas de espuma, a intermitência dos seus (des)encontros com Arcanjo... Movimento, também ele, inscrito no seu corpo de crisálida, ao sonhar-se grávida dele: 
Sucedia comigo a mesma clausura que, num dado momento, ocorre com as borboletas. Eu migrava para um casulo, embrulhada no tempo e esperando que uma outra criatura emergisse em mim (ibidem, p. 198).

Não admira, pois, que seu tio-avô Adjiru - que é, também, quem lhe ensina as primeiras letras... - houvesse sido, para além de caçador, quer escultor de máscaras, quer um exímio contador de histórias. Com ele dançariam já as palavras:

Os homens perguntavam ao avô Adjiru sobre as aventuras de caça. [...] $\mathrm{Na}$ verdade, não recordava a caçada: ele voltava a caçar. [...] Conte outra história Adjiru. Conte aquela vez... Em reprovação, o avô erguia o braço. Negava o convite: no relato do caçador não existe o "era uma vez". Porque tudo nasce ali, na vez da sua voz. Contar uma história é deitar sombras ao lume. Tudo o que a palavra revela é, nesse mesmo instante, consumido pelo silêncio (ibidem, p. 99).

Deitar sombras ao lume: iluminar - não apenas o que do seu obscuro âmago provém, mas também o que a ele regressa, "nesse mesmo instante, consumido pelo silêncio"... A figura de Mariamar se nos recortaria, então - sobre o fundo de uma qualquer história da mulher como a recordada, em "Sorties", por Hélène Cixous:

Woman's voyage: as a body. As if she were destined in the distribution established by men (separated from the world where cultural exchanges are made and kept in the wings of the social stage when it is the case of History) - to be the nonsocial, nonpolitical, nonhuman half of the living structure. On nature's side of this structure, of course, tirelessly listening to what goes on inside - inside her belly, inside her 'house'. In direct contact with her appetites, her affects $(1975$, p. 66).

E nos recordaria o que Hélène Cixous nos diria, então, da figura da histérica:

Woman have not sublimated. Fortunatley. They have saved their skins and their energy. They haven't worked at planning the impass of futureless lives.
They have furiously inhabited these sumptuous bodies. Those wonderful hysterics, who subjected Freud to so many voluptuous moments too shameful to mention, [...] they were dazzling. [...] It is you, Dora, you, who cannot be tamed, the poetic body, the true 'mistress' of the Signifier. Before tomorrow your efectiveness will be seen at work - when your words will no longer be retracted, pointed against your own breast, but will write themselves against the other and against men's grammar (ibidem, p. 95; grifos meus).

\section{Referências}

AGAMBEN, Giorgio. O poder soberano e a vida nua. Lisboa: Presença, 1998.

AGAMBEN, Giorgio. A potência do pensamento. Lisboa: Relógio d'Água, 2013.

BENJAMIN, Walter. Rua de sentido único e infância em Berlim por volta de 1900. Lisboa: Relógio d'Água, 1992.

BUTLER, Judith. Precarious life. London: Verso, 2006.

CIXOUS, Hélène; CLÉMENT, Catherine. Newly born woman. london: Tauris, 1975.

COUTO, Mia. A confissão da Leoa. Lisboa: Caminho, 2012.

DERRIDA, Jacques. Points de suspension. Paris: Galilée, 1992.

DERRIDA, Jacques. L'animal que donc je suis. Paris: Galilée, 2006.

DERRIDA, Jacques. Le souverain Bien / O soberano Bem. Viseu: Palimage, 2004.

DIDI-HÜBERMAN, Georges. Falenas: ensaios sobre a aparição 2. Lisboa: KKYM, 2015.

FREUD, Sigmund. Obras completas. Madrid: Biblioteca Nueva, 1997. Tomo 9.

LACAN, Jacques. Os complexos familiares. Rio de Janeiro: Jorge Zahar, 1985.

LACAN, Jacques. Écrits II. Paris: Seuil, 1999.

LACAN, Jacques. O avesso da psicanálise: 1969-1970. Rio de Janeiro: Jorge Zahar, 1992.

Recebido: 23 de novembro de 2015

Aprovado: 11 de março de 2016

Contato:.jplmcpereira@gmail.com 